KuLTura - MeDia- TeoLogia ISSN 2081-8971

$2017 \mathrm{nr} 30$, s. 137-150.

\title{
Dziennikarstwo śledcze w przestrzeni lokalnej. Analiza prasoznawcza publikacji „Dziennika Zachodniego” z 2015 roku
}

\author{
Investigative journalism in the local space. \\ The scientific analysis of the publications in "Dziennik Zachodni" since 2015.
}

\section{STRESZCZENIE:}

AUTORKA DOKONAŁA ANALIZY ZAWARTOŚCI ROCZNIKA „DZIENNIKa ZaCHODNIEGO” Z 2015 ROKU POSZUKUJĄC PUBLIKACJI DZIENNIKARSKICH O CHARAKTERZE ŚLEDCZYM. MOTYWACJĄ DO PRZEPROWADZENIA ANALIZY BYŁY PYTANIA BADAWCZE: ILE JEST TAKICH MATERIAŁÓW

W PRASIE LOKALNEJ NA PRZYKŁADZIE „DZIENNIKA ZACHODNIEGO”, JAK CZĘSTO SĄ PUBLIKOWANE, KTO JE PISZE, O KIM PISZE, ORAZ JAKĄ POWIERZCHNIE MAJĄ TE TEKSTY WZGLĘDEM INNYCH MATERIAEÓW DZIENNIKARSKICH.

PIERWSZA CZEŚĆ ARTYKUŁU ZARYSOWUJE NAM HISTORIE DZIENNIKARSTWA ŚLEDCZEGO W USA I MEDIÓW W POLSCE PO 1989 R. W DALSZEJ KOLEJNOŚCI ZAPREZENTOWANE SĄ FUNKCJONUJĄCE W LITERATURZE DEFINICJE DZIENNIKARSTWA ŚLEDCZEGO, A TAKŻE NAJWAŻNIEJSZA PROBLEMATYKA I CECHY TYCH PUBLIKACJI. W CZĘŚCI KOLEJNEJ AUTORKA PRZEDSTAWIA CEL SWOICH BADAŃ, ORAZ METODOLOGIĘ, A NASTĘPNIE WYNIKI TYCH BADAŃ.

\section{SŁOWA KLUCZOWE:}

POLSKIE DZIENNIKARSTWO ŚLEDCZE, DZIENNIKARSTWO LOKALNE, PRASA LOKALNA

\begin{abstract}
:
THE AUTOR ANALYZED „DZIENNIK ZACHODNI" YEARBOOK OF 2015 SEARCHING INVESTIGATIVE JOURNALISM PUBLICATIONS. MOTIVATION FOR THE ANALYSIS WAS RESEARCH QUESTIONS: FREQUENCY OF PUBLICATIONS, WHO IS ITS AUTOR, WHO THE AUTOR IS WRITING ABOUT, WHAT IS IT'S SURFACE COMPARED TO SURFACE OF OTHER PUBLICATIONS.

THE FIRST PART OF THE ARTICLE OUTLINES THE HISTORY OF INVESTIGATIVE JOURNALISM IN THE US AND THE MEDIA IN POLAND AFTER 1989. IN THE SECOND PART OF THE ARTICLE ARE PRESENTED FUNCTIONING DEFINITIONS OF INVESTIGATIVE JOURNALISM IN LITERATURE, AS WELL AS THE MOST IMPORTANT ISSUES AND FEATURES OF THESE PUBLICATIONS. IN THE NEXT PART THE AUTHOR PRESENTS THE PURPOSE OF HIS RESEARCH, THE METHODOLOGY AND THE RESULTS OF THESE STUDIES.
\end{abstract}

\section{KEYWORDS:}

POLISH INVESTIGATIVE JOURNALISM, LOCAL JOURNALISM, LOCAL PRESS 
$\mathrm{D}$ ziennikarstwo śledcze można niewątpliwie określić mianem społecznej misji. Jest to jednocześnie jedna $\mathrm{z}$ najtrudniejszych odmian tego zawodu - biorąc pod uwagę fakt, że rezultaty pracy dziennikarza śledczego są oddalone w czasie, a powstanie tekstu dziennikarskiego, jako zwieńczenia tej pracy, nie zawsze jest możliwe. Dziennikarz śledczy często boryka się z utratą zdrowia i życia ze strony tych, których interesy narusza; nierzadko zmaga się również z długotrwałymi i wyniszczającymi procesami sądowymi w sprawach o naruszenie dóbr osobistych czy zniesławienie. Między innymi z tych powodów redakcje niechętnie podejmują się realizacji trudnych i kontrowersyjnych tematów. Wielu pracowników prowadzących dziennikarskie dochodzenia nie lubi, gdy określa się ich mianem dziennikarzy śledczych. Traktują oni swą pracę po prostu jako robienie czegoś pożytecznego - co jest dla nich istotą tego zawodu, w myśl zasady, iż „w modelowym ujęciu dziennikarze nie mają własnych preferencji politycznych, redakcje - linii programowych, świat mediów, wolny od nacisków ekonomicznych będących efektem splotu interesów biznesu i polityki, z jednakową determinacją tropi nieprawidłowości władzy, nadaje im rozgłos"1.

Niektórzy uważają, że dziennikarstwu śledczemu dała początek afera Watergate w USA; inni, że jego źródeł należy szukać znacznie wcześniej, bo w 1690 roku Bostonie, kiedy to Benjamin Harris ujawnił w swym periodyku „Public Occurrences, Both Foreign and Domestick” fakt torturowania jeńców francuskich przez Indian służących Anglikom².

Niestety, wkrótce po publikacji władze zamknęły tytuł Benjamina Harrisa i przez długie lata nikt nie podjął się realizacji misji dziennikarskiej w takim stylu. Stało się to dopiero w latach 70., kiedy to za sprawą dwóch dziennikarzy „The Washington Post”, świat dowiedział się o nadużyciach prezydenta Nixona i jego otoczenia. Dwaj dziennikarze, Carl Bernsten i Bob Woodward z „The Washington Post”, stali się bohaterami i tej oceny nie zmienia nawet ujawniony niedawno fakt, że byli wspomagani, a właściwie naprowadzani na trop przez ówczesnego zastępcę szefa FBI”’3.

Afera Watergate na stałe już stała się częścią kanonu dziennikarstwa śledczego i uchodzi za przykład i często początek tej odmiany dziennikarstwa. Długa tradycja dziennikarstwa śledczego w Stanach Zjednoczonych, znanego tam jako investigative reporting, czyni go powszechnym zjawiskiem w gazetach codziennych. Wojciech Adamczyk zauważa wiele analogii między publikacjami o naturze śledczej w Stanach Zjednoczonych i w Polsce. Jak pisze, „owe podobieństwa dotyczą zarówno poruszanej tematyki, zastosowanych metod pozyskiwania informacji oraz ich weryfikacji, jak i skutków tych dochodzeń odczuwalnych w obszarach polityki, ekonomii i stosunków społecznych"4 -

\footnotetext{
${ }^{1}$ I. Hofman, Polityka, media, społeczeństwo. Studia i szkice, Toruń 2007, s. 84.

${ }^{2}$ W. Adamczyk, Ujawnianie korupcji i nadużyć władzy w działalności amerykańskich muckrakerów, w: M. Palczewski, M. Worsowicz (red.), Dziennikarstwo śledcze. Teoria i praktyka w Polsce, Europie i Stanach Zjednoczonych, Łódź 2006, s. 16.

${ }^{3}$ T. Goban-Klas, Dziennikarstwo śledcze w USA. Powstanie, rozkwit, rozkład, w: M. Palczewski, M. Worsowicz (red.), Dziennikarstwo śledcze..., dz. cyt., s. 10.

${ }^{4}$ W. Adamczyk, Rzecz o kontynuacji: amerykańskie wzorce investigative reporting ${ }^{w}$ praktyce polskich reporterów śledczych, w: News i dziennikarstwo śledcze wobec wyzwań XXI wieku, M. Palczewski, M.
} 
przy czym autor ten nie upatruje przyczyn podobieństwa w naśladownictwie, z uwagi na dość krótką popularyzację investigative reporting $w$ Polsce.

Ujawnianie, dociekanie i wyciąganie na światło dzienne różnych patologii dało początek stylowi dziennikarskiemu, który wobec władz i elit wypełnia jedną z najważniejszych funkcji mediów - funkcję kontrolną i krytykującą. Dodajmy, że uprawianie tego zawodu możliwe jest w tych systemach politycznych, gdzie istnieje wolność słowa, ponieważ „podstawą politycznej krytyki i kontroli jest niezależność (wolność od nacisków) podmiotów formułujących sądy i opinie, niezależność ta musi być oparta na ogólnej wolności informacji” ${ }^{5}$. Jednak, jak wykazuje analiza amerykańskiej organizacji Freedom House National Headquarters, wolność prasy jest na świecie dobrem deficytowym: państw, gdzie media mogą wypełniać swą misję i rolę policjanta wobec władz, jest w skali globu niewiele (rysunek $\mathrm{nr}$ 1). Tymczasem, niezależne media cieszące się wolnością słowa są filarem i strażnikiem demokracji, a dziennikarze dążący do prawdy, tropiący nadużycia różnego rodzaju elit, będą zawsze cieszyli się poparciem społecznym.

\section{Rysunek nr 1.}

\section{MAP OF PRESS FREEDOM}

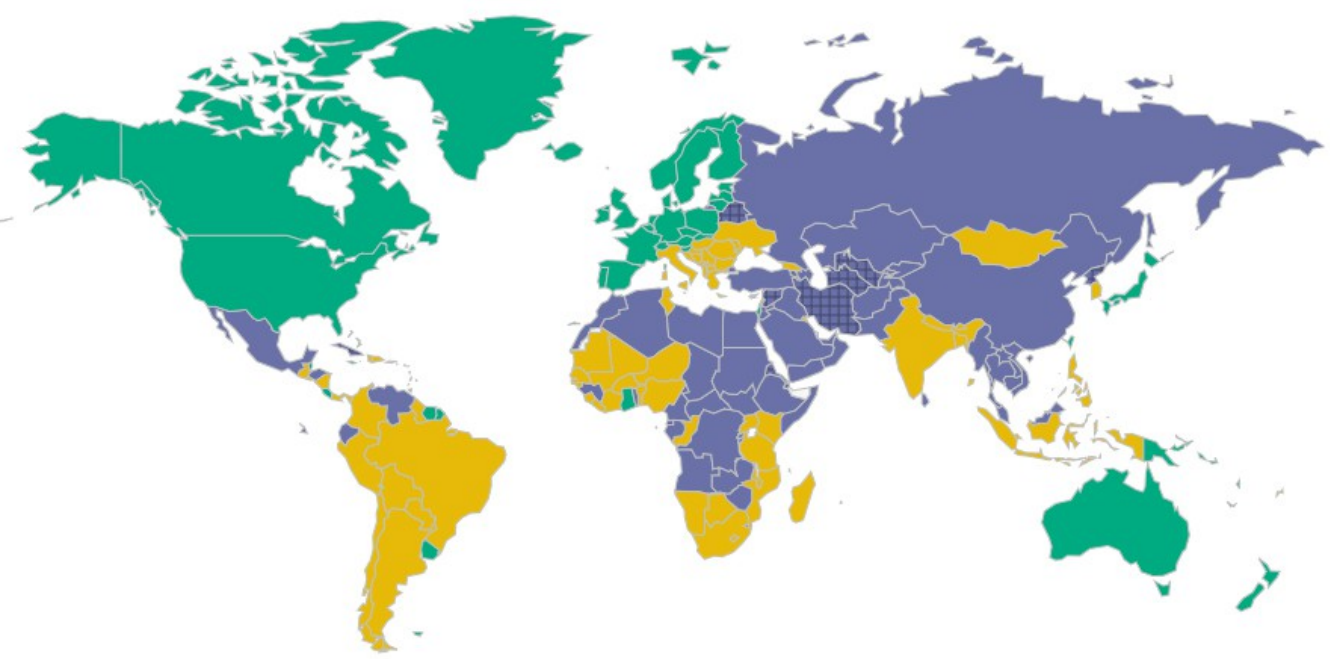

Freedom of the Press

Free Partly Free Not Free 10 Worst of the Worst

\section{Źródło:www.freedomhouse.org}

Worsowicz (red.), Łódź 2010, s. 113.

${ }^{5}$ S. Michalczyk, Komunikowanie polityczne. Teoretyczne aspekty procesu, Katowice 2005, s. 129. 
Współczesne polskie dziennikarstwo śledcze rozwija się od 1989 roku, co ma związek z przekształceniami strukturalnymi prasy, radia i telewizji. Materiały dziennikarskie odkrywające nieprawidłowości i skandale w świecie polityki, biznesu, organizacji społecznych i religijnych na stałe zagościły na łamach gazet, w eterze i na wizji. Przed 1989 r. komunistyczni decydenci poprzez działania cenzorów i rozmaite represje nie dopuszczali do ujawniania patologii. Dopiero przemiany uwolniły potencjał zawodowy dziennikarzy i dały polskim mediom możliwość wypełniania pierwotnych funkcji wobec społeczeństwa, a co za tym idzie, zyskały przydomek tzw. „,zwartej władzy”. Odtąd media „,pełnią rolę zwierciadła opinii publicznej, adwokata obywateli, organu narodu oraz pośrednika w kształtowaniu woli politycznej”6. I tak, w maju 1989 r. powstał pierwszy niezależny dziennik: „Gazeta Wyborcza”, który zaanektował wielu dziennikarzy „Tygodnika Mazowsze”. Rozpoczął się ciąg zmian na rynku mediów. Nastąpiła likwidacja cenzury, nowelizacja prawa prasowego (która miała być tylko tymczasowa; docelowo planowano napisać ustawę od nowa, co nigdy nie doszło do skutku) i demontaż RSW „Prasa-Książka-Ruch”. Zaczęto anektować tytuły koncernu „Prasa-Książka-Rucha”, a także zakładać nowe pisma o zasięgu ogólnopolskim i lokalnym. Według Ryszarda Kowalczyka w latach 1990-1991 utworzono 80 tytułów regionalnych oraz 615 lokalnych, podczas gdy niewiele z pism istniejących przed 1989 rokiem przetrwało ${ }^{7}$. Nastąpił dynamiczny rozwój prasy lokalnej, ale ,zakładane w wielu miastach nowe dzienniki w większości nie zdołały utrzymać się na rynku, a ich założyciele przekonali się szybko, że rynek prasowy brutalnie weryfikuje idealistyczne założenia".

\section{Ustalenia definicyjne}

Dziennikarstwo śledcze wraz z wolnością słowa zagościło na stałe w polskich mediach - stało się też przedmiotem zainteresowania badaczy. Na polskim gruncie istnieje dziś wiele definicji dziennikarstwa śledczego, uzupełniających się lub powielających - zarówno wśród praktyków, jak i teoretyków mediów. Stanisław Michalczyk zauważa, że w medioznawstwie dziennikarstwo śledcze jest jednym z trzech typów idealnych i stoi w typologii obok dziennikarstwa informacyjnego i interpretacyjnego, a sam dziennikarz śledczy „występuje w roli "czuwającego psa" (watchdogs, Wachshund), oraz rzecznika opinii publicznej. Jego podstawowym zadaniem jest krytyka i kontrola, ma duży zakres autonomii i stawiane są mu wysokie wymagania kompetencyjne" ${ }^{\text {. Z }}$ kolei Wojciech Adamczyk widzi dziennikarstwo śledcze jako demaskowanie ,świadomie ukrytych przed społeczeństwem bezprawnych i amoralnych zachowań ludzi władzy oraz wielkiego biznesu" ${ }^{10}$. To samo, acz innymi słowami, mówi nam o dziennikarstwie śledczym dziennikarz Bertold Kittel, twierdząc, iż „dzienni-

\footnotetext{
${ }^{6}$ K. Brzoza, Rola „Dziennika Zachodniego” $w$ wyborach samorządowych 2014 r., w: Oblicza mediów lokalnych i regionalnych, S. Michalczyk, D. Krawczyk (red.), Mikołów 2016, s. 67.

${ }^{7}$ R. Kowalczyk, Media lokalne w Polsce. Podręcznik akademicki, Poznań 2009, s. 96-100.

${ }^{8}$ J. Braun, Potęga czwartej władzy, Warszawa 2005, s. 130.

${ }^{9}$ S. Michalczyk, Komunikowanie polityczne..., dz. cyt., s. 196.

${ }^{10}$ W. Adamczyk, Skandal na pierwszej stronie. Sensacyjność jako element oceny wiarygodności śledztw dziennikarskich, w: M. Palczewski, M. Worsowicz (red.), O dziennikarstwie śledczym. Normy, zagrożenia, perspektywy, Łódź 2009, s. 28.
} 
karstwo śledcze to dotarcie możliwie jak najbliżej prawdy poprzez weryfikację informacji na ważny społecznie temat $w$ drodze dziennikarskiego dochodzenia - i przekazanie zgromadzonego tą drogą materiału opinii publicznej" ${ }^{11}$. Anna Marszałek uzupełnia powyższe definicje o niezwykle istotny element roli służb publicznych: „wyróżnia się ono niezależnością od ustaleń wszystkich innych, powołanych do tego organów, jak: policja, służby specjalne i wywołuje wymierny skutek w postaci wszczęcia śledztwa"12.

Analizując teksty śledcze, Monika Worsowicz kładzie nacisk na budowę i gatunek dziennikarski; tekst o charakterze śledczym jest to więc „publikacja prasowa o znacznej objętości, często skomplikowanej strukturze, niejednorodna pod względem gatunkowym; poświęcona ujawnieniu faktów mających istotny wpływ na życie publiczne, porządek społeczny publiczny i/lub prawny; jest efektem zazwyczaj długotrwałego, niejawnego ustalania przez dziennikarzy przebiegu zdarzeń (śledztwa) prowadzącego do publicznej kompromitacji osób, których szkodliwe działania zostały opisane w tekście; inicjuje publiczną dyskusję na dany temat oraz zapoczątkowuje - częściej - intensyfikuje działania organów ścigania w opisanej sprawie" ${ }^{" 13}$. Wydaje się, że autorka zawarła w tej definicji wszystkie cechy tekstu o charakterze śledczym.

Niektórzy praktycy twierdzą, iż dziennikarstwa śledczego nie należy odróżniać od dziennikarstwa w ogóle; że wypełnianie misji, tropienie nieprawidłowości i ujawnianie ich mieści się w definicji samego dziennikarstwa. Realizacja misji dziennikarskiej i funkcjonowanie w ramach czwartej władzy odnosi się przecież do dziennikarstwa w ogóle, choć często podkreślane jest w charakterystyce dziennikarstwa śledczego. Jednakże, trzeba zauważyć, że tekst dziennikarski o charakterze śledczym różni się znacząco typowego tekstu dziennikarskiego: ma nutę sensacyjności. W publikacji tej dziennikarz stawia zarzuty i publikuje dowody w postaci „zeznań” świadków, kopii dokumentów - co ma mobilizować opinię publiczną, a czasami także służby publiczne. Maciej Mrozowski twierdzi, iż dziennikarstwo śledcze, czyli „publikacje demaskujące wszelkiego rodzaju nadużycia i niegodziwość polityków" ${ }^{14}$, to rodzaj dziennikarstwa, który podnosi reputację samego dziennikarstwa, a gazety chętnie ujawniają patologie dotyczące polityków"15.

$\mathrm{Na}$ podstawie funkcjonujących w literaturze definicji dziennikarstwa śledczego można wyłonić następujące cechy publikacji śledczych:

- demaskowanie wszelkiego rodzaju nadużyć;

- niezależność ustaleń dziennikarza od pracy organów ścigania i innych służb;

- często dwie relacje: o wydarzeniach związanych z pewnymi faktami oraz o odkrywaniu prawdy na ten temat;

\footnotetext{
${ }^{11}$ B. Kittel, Dziennikarz z dymiącą strzelbą, w: A. Skworza, A. Niziołek (red.), Biblia dziennikarstwa, Kraków 2010, s. 110 .

${ }^{12}$ I. Hofman, Polityka, media, społeczeństwo..., dz. cyt. s. 94-95.

${ }^{13}$ M. Worsowicz, Pragmatyka tekstów śledczych. Wybrane zagadnienia, w: M. Palczewski, M. Worsowicz (red.), Dziennikarstwo śledcze. Teoria..., dz. cyt., s. 123-124.

${ }^{14}$ M. Mrozowski, Media masowe. Władza, rozrywka i biznes, Warszawa 2001, s. 132-133.

${ }^{15}$ Tamże.
} 


\section{OBLICZA MEDIÓW I KOMUNIKACJI}

- konwencja reportażu lub wywiadu, ułatwiająca lekturę;

- nadana tekstowi dramaturgia poprzez konfrontowanie ustaleń dziennikarza z wypowiedziami bohaterów oraz relacjonowanie tego, co różne źródła mówią o tym samym fakcie.

$\mathrm{Z}$ wymienionych cech dwie wydają się być najważniejsze (bez nich tekst śledczy nie mógłby zaistnieć) - są to „demaskowanie nadużyć” oraz „, niezależność ustaleń od organów ścigania”.

Media regionalne i lokalne w dobie dominacji mediów elektronicznych borykają się z licznymi problemami. Znawcy tej tematyki wskazują na wiele negatywnych zmian z tym związanych, a nawet „pojawiają się hipotezy o zmierzchu czy wręcz końcu epoki mediów papierowych"16. Samo dziennikarstwo śledcze to także dziennikarstwo lokalne. Małgorzata Wyszyńska wartykule „Press” przybliżyła sylwetki pięciu dziennikarzy z różnych tygodników lokalnych, zajmujących się tropieniem patologii - stawiając przy tym tezę, że to właśnie w mediach lokalnych dziennikarstwo śledcze jest dobrze rozwinięte ${ }^{17}$. Czy jednak kilka pozytywnych przykładów żurnalistów jest w stanie zmienić panującą powszechnie opinię w świecie o mediach lokalnych jako tych, które są w recesji także jeśli chodzi o ujawnianie nadużyć i patologii? Czy przewidywany zmierzch mediów lokalnych, walka redakcji o przychylność miejscowych władz czy biznesów, uleganie oddziaływaniu reklamodawców, może iść w parze z demaskacją lokalnych „przekrętów"? W dalszej części artykułu zaprezentowane zostaną wyniki analizy empirycznej, która ma odpowiedzieć między innymi na tak postawione pytania.

\section{Cel i metodologia badań}

Intencją autorki było sprawdzenie, ile materiałów o charakterze demaskatorskim ukazało się w ciągu roku w największym dzienniku regionalnym w Polsce. Celem analizy zawartości „Dziennika Zachodniego” było określenie stopnia zainteresowania mediów lokalnych ujawnianiem nieprawidłowości, a także odpowiedź na pytanie, jak często dziennikarze podejmują trudne i kontrowersyjne tematy przybliżające społeczeństwu to, co ktoś chce ukryć. Analizę oparto na danych ilościowych, czyli liczbie tekstów będących wynikiem śledztwa dziennikarskiego. Analiza jakościowa miała dać odpowiedź na pytanie, kto jest przedmiotem zainteresowania dziennikarzy, ilu dziennikarzy publikuje teksty o charakterze śledczym, jaka jest powierzchnia tych tekstów względem innych materiałów dziennikarskich, a także jak wyeksponowane są te materiały i do jakiego gatunku dziennikarskiego należą.

Źródłem informacji był rocznik „Dziennika Zachodniego”, zawierający numery wydawane od 2 stycznia do 31 grudnia 2015 r. Łącznie były to 304 numery, w tym 248 pojedynczych, 53 podwójnych i 3 potrójne. Analizę przeprowadzono w październiku 2016 roku.

\footnotetext{
${ }^{16}$ M. Kornacka, Zmierzch prasy lokalnej? Ograniczenia w rozwoju prywatnych tytułów lokalnych na przykładzie Śląska Cieszyńskiego, w: W. Furman, P. Kuca (red.), Przemiany mediów regionalnych i lokalnych, Rzeszów 2015, s. 45.

${ }^{17}$ M. Wyszyńska, Lokalni tropiciele, „Press” nr 7-8.2016, s. 70-72.
} 
Wyboru tegoż dziennika dokonano nie bez powodu. „Dziennik Zachodni” wydawany jest od 1945 roku i jest największą gazetą regionalną w Polsce. Swym zasięgiem obejmuje 22 powiaty na terenie województwa śląskiego i małopolskiego. Wydawcą pisma jest spółka Polska Press Oddział Prasa Śląska. „Dziennik Zachodni” jest liderem w kategorii średniej sprzedaży wśród dzienników regionalnych i lokalnych (średnia sprzedaż „Dziennika Zachodniego” w styczniu 2015 roku wyniosła 45464 egzemplarzy - Wirtualne Media). Badania czytelnictwa przeprowadzone przez Millward Brown w okresie od stycznia do grudnia 2015 roku wskazują, że w województwie śląskim, w grupach wiekowych od 15 do 75 i od 16 do 59 lat, jest on najchętniej czytanym dziennikiem, a także liderem sprzedaży wśród dzienników regionalnych i lokalnych ${ }^{18}$.

\section{Dziennik Zachodni - wyniki analizy}

„Dziennik Zachodni” w 2015 roku zawierał od 16 do 52 stron, co daje średnią 28 stron w jednym numerze. Najwięcej wydano numerów 24 i 28 -stronicowych.

Tabela nr 1: Numery „Dziennika Zachodniego” w 2015 roku z liczbą stron

\begin{tabular}{|c|c|}
\hline Liczba stron & Liczba numerów \\
\hline 16 & 19 \\
\hline 20 & 14 \\
\hline 22 & 1 \\
\hline 24 & 98 \\
\hline 26 & 4 \\
\hline 28 & 95 \\
\hline 30 & 1 \\
\hline 32 & 15 \\
\hline 36 & 17 \\
\hline 40 & 28 \\
\hline 44 & 10 \\
\hline 48 & 1 \\
\hline 52 & 1 \\
\hline „Dzienniku Zachodnim & 28 \\
\hline
\end{tabular}

Źródło: opracowanie własne.

${ }^{18}$ Duże zmiany w czytelnictwie dzienników $\mathbf{w}$ województwach,

http://www.wirtualnemedia.pl/artykul/duze-zmiany-w-czytelnictwie-dziennikow-w-wojewodztwach [data dostępu 10.12.2017];

„Fakt” nowym liderem w trzech regionach. Czytelnictwo dzienników w województwach, http://www.wirtualnemedia.pl/artykul/fakt-nowym-liderem-w-trzech-regionach-czytelnictwodziennikow-w-wojewodztwach [data dostępu 10.12.2017]; Czytelnictwo dzienników w województwach: nowi liderzy w sześciu regionach, http://www.wirtualnemedia.pl/artykul/czytelnictwo-dziennikow-wwojewodztwach-nowi-liderzy-w-szesciu-regionach [data dostępu 10.12.2017]; Duże zmiany w regionalnym czytelnictwie dzienników. Nowi liderzy w siedmiu województwach,

http://www.wirtualnemedia.pl/artykul/duze-zmiany-w-regionalnym-czytelnictwie-dziennikow-nowiliderzy-w-siedmiu-wojewodztwach/page:2 [data dostępu 10.12.2017]; Duże zmiany w czytelnictwie dzienników w województwach. Siedem regionów z nowymi liderami, http://www.wirtualnemedia.pl/artykul/duze-zmiany-w-czytelnictwie-dziennikow-w-wojewodztwachsiedem-regionow-Z-nowymi-liderami [data dostępu 10.12.2017]. 
Dokonano analizy 10032 publikacji z wyłączeniem artykułów sponsorowanych, reklam i ogłoszeń.

Wykres nr 1 .

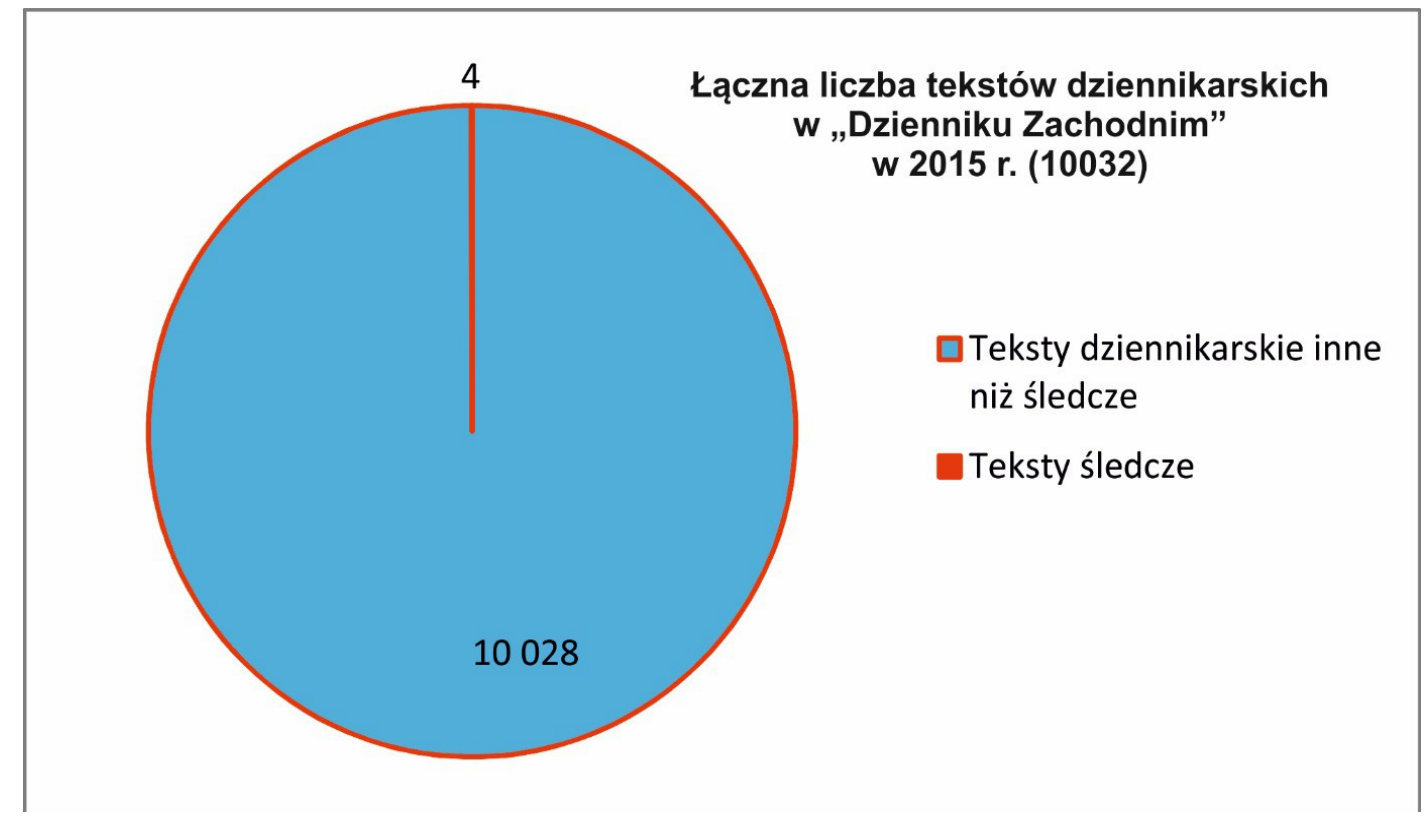

Źródło: opracowanie własne.

Przyjęto następujące kryteria klasyfikowania tekstów do dalszej analizy: posiadanie przez publikacje cech demaskatorskich, bycie niezależnymi wobec władz lokalnych, bycie istotnymi z punktu widzenia opinii publicznej. Spośród ponad 10 tys. tekstów stanowiących materiał badawczy, w trakcie analizy ilościowej wyłoniono tylko 4 teksty o charakterze śledczym (tabela $\mathrm{nr} 2$ ). Trzy z nich („Wielkie interesy króla żylaków i białych zębów”, „Miał być cudowny lek. Są same kłopoty”, „Król białych zębów ma zarzut. Nie może wyjechać z Polski”) to cykl, w którym dziennikarze ujawniają kulisy interesów młodego biznesmena, który dorobił się majątku na handlu parafarmaceutykami. Produkty te, rzekomo zawierające nowe, wspaniałe receptury zachwalane przez lekarzy, okazały się substancjami o znanych i prostych składach, a polecający owe specyfiki lekarze w rzeczywistości nie mieli o nich pojęcia, albo zwyczajnie nie istnieli. W rezultacie pracy dziennikarzy cudotwórcza substancja na żylaki, a także pasta do zębów (sprzedawana w Anglii) okazują się być oszustwem, a sprawa znajduje swój finał w sądzie, o czym mówi ostatni z tekstów („Król białych zębów ma zarzut. Nie może wyjechać z Polski”). 
Tabela nr 2.

\begin{tabular}{|c|c|c|c|c|c|c|c|}
\hline Numer & Tytuł & Autor & Strona & Objętość & $\begin{array}{l}\text { Zapowiedź } \\
\text { na } 1 \text { stronie }\end{array}$ & Zakres tematyczny & $\begin{array}{l}\text { Źródła informacji } \\
\text { przed podjęciem } \\
\text { tematu }\end{array}$ \\
\hline 5-6.01.2015 & $\begin{array}{l}\text { "Migdałowy } \\
\text { dym", Powrót } \\
\text { dopalaczy" }\end{array}$ & $\begin{array}{l}\text { P. Ciastek } \\
\text { J. Strzelczyk }\end{array}$ & $10 / 32$ & $18 \times 19 \mathrm{~cm}$ & nie & $\begin{array}{l}\text { Ujawnienie nielegalnego } \\
\text { handlu dopalaczami }\end{array}$ & Brak danych \\
\hline 19.01.2015 & $\begin{array}{l}\text { „Wielkie } \\
\text { interesy króla } \\
\text { żylaków i } \\
\text { białych zębów” }\end{array}$ & M. Czerniak & $\begin{array}{l}18- \\
19 / 28\end{array}$ & $\begin{array}{l}29 \times 35 x \\
2 \text { strony }\end{array}$ & tak & $\begin{array}{l}\text { Ujawnienie nieuczciwych } \\
\text { praktyk w sprzedaży } \\
\text { parafarmaceutyków }\end{array}$ & Czytelnicy \\
\hline 20.01 .2015 & $\begin{array}{l}\text { „Miał być } \\
\text { cudowny lek. Są } \\
\text { same kłopoty" }\end{array}$ & $\begin{array}{l}\text { M. Czerniak, } \\
\text { Ł. Cieśla }\end{array}$ & $11 / 28$ & $29 \times 35$ & nie & $\begin{array}{l}\text { Ujawnienie nieuczciwych } \\
\text { praktyk w sprzedaży } \\
\text { parafarmaceutyków }\end{array}$ & - \\
\hline 16.02 .2015 & $\begin{array}{l}\text { „Król białych } \\
\text { zębów ma } \\
\text { zarzut. Nie może } \\
\text { wyjechać z } \\
\text { Polski” }\end{array}$ & M. Czerniak & $14 / 28$ & $18 \times 15,5$ & nie & $\begin{array}{l}\text { Ujawnienie nieuczciwych } \\
\text { praktyk w sprzedaży } \\
\text { parafarmaceutyków }\end{array}$ & - \\
\hline
\end{tabular}

Źródło: opracowanie własne.

Natomiast publikacja „Migdałowy dym. Powrót dopalaczy” dotyczy ujawnienia nielegalnego handlu dopalaczami. Tym razem dziennikarze prowokują nielegalną sprzedaż: kupują dopalacze, posługując się zasłyszanym wcześniej hasłem „za 20”. W tym przypadku czytelnik nie dowiaduje się, jaki był ciąg dalszy nielegalnego procederu. Artykuł kończy się informacją o tym, że dopalacze projektowane są komputerowo i trudno z nimi walczyć, bo na rynek trafiają coraz to nowsze ich wersje, mające nowe składy chemiczne.

W obu przypadkach (materiał o dopalaczach oraz 3 artykuły dotyczące parafarmaceutyków) dziennikarze przeprowadzają swoje śledztwa w tzw. tandemie, która jest typową metodą w przypadku dziennikarskiej pracy śledczej: „W sprawach dochodzeniowych praca w tandemie jest niemal regułą. Dziennikarze działają wtedy podobnie jak policjanci, którzy w terenie pracują we dwóch, ubezpieczając się nawzajem" 19 .

Wszystkie analizowane teksty opublikowano na początku roku 2015 i stanowia 0,042\% całości rocznika (wykres nr 2). Uściślić należy, że wyliczenie procentowe dotyczy powierzchni udziału materiałów śledczych w „Dzienniku Zachodnim”, a więc w numerach, gdzie występowały teksty śledcze, zajmowały one od około $1 \%$ do ponad $7 \%$ powierzchni (wszystkich materiałów dziennikarskich), co obrazuje poniższy wykres. Wszystkie teksty śledcze, które udało się odnaleźć w trakcie analizy, dotyczyły biznesu: raczej małego, niż wielkiego.

\footnotetext{
${ }^{19} \mathrm{~J}$. Łęski, Źródła informacji i techniki pracy stosowane w dziennikarstwie dochodzeniowym. Uwagi warsztatowe, w: A. Hejman (red.), Poradnik dla wydawców i dziennikarzy prasy lokalnej, tom 3, Warszawa 1998, s. 213.
} 


\section{Wykres nr 2}

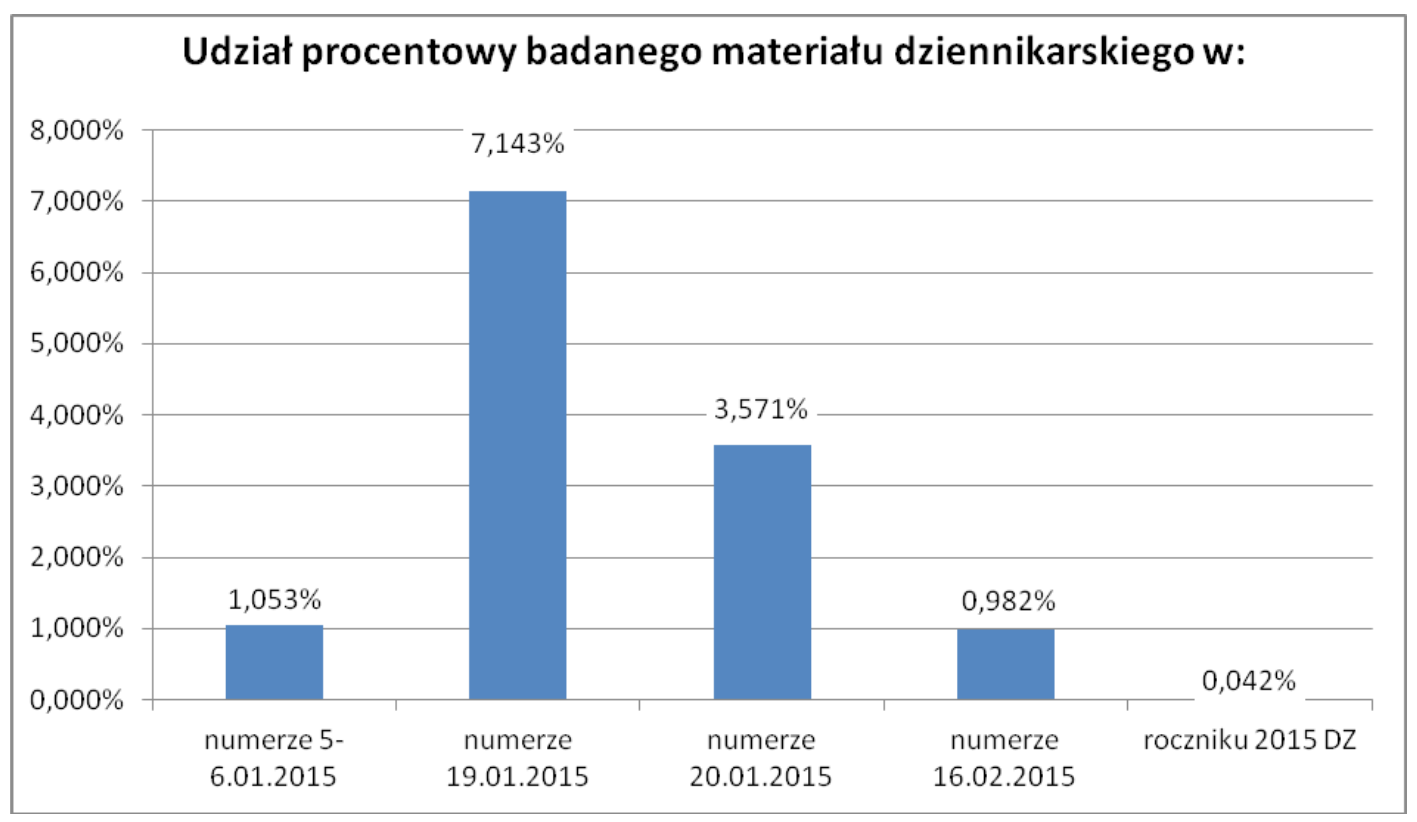

Źródło: opracowanie własne.

Publikacja tekstu śledczego $\mathrm{w}$ danym numerze stanowi dla redakcji ważny dzień, zwane w żargonie „wodowaniem”. W napięciu oczekuje się reakcji opinii publicznej, a także innych dziennikarzy. Istotą takiego tekstu jest przecież zainicjowanie dyskusji publicznej, a jeśli sprawa tego wymaga, również akceleracja działań organów ścigania. Wcześniej w redakcji pracuje się nad tym, by odpowiednio wyeksponować tekst w ramach pisma. Elementem, który potwierdza doniosłość publikacji w prasie, jest ekspozycja na okładce jego zapowiedzi, odpowiednia ekspozycja nadtytułów, tytułów i lidów. Wśród analizowanych materiałów tylko jeden z tekstów miał zapowiedź na okładce („Wielkie interesy króla żylaków i białych zębów”), zajmował 2 strony (wymiar gazety: 29x55cm), czyli 12 szpalt, i opatrzony został grafikami. Dwie publikacje („Migdałowy dym. Powrót dopalaczy”, „Miał być cudowny lek. Są same kłopoty”) miały po jednej nawiązującej do tematu tekstu fotografii, przy czym jedna z nich była tylko relacją ze śledztwa policyjnego, bez grafik („Król białych zębów ma zarzut. Nie może wyjechać z Polski”).

Sytuacja lub sytuacje, które bywają przedmiotem dziennikarskiego śledztwa, są zazwyczaj skomplikowane i wielowątkowe. Jeśli taki tekst zostanie nieumiejętnie zaprezentowany, czytelnik może mieć wrażenie chaosu. Nie sprzyja także przejrzystości w tekście śledczym konwencja reportażowa $\mathrm{z}$ dwiema relacjami o wydarzeniach oraz o odkrywaniu prawdy na ten temat. Zaleca się zatem „,wzbogacenie tekstu (...) o elementy, które 
ułatwiają jego zrozumienie i interpretację, jak: ikonografiki wizualizujące kolejne etapy rozwoju śledztwa lub działania bohaterów, krótkie sylwetki postaci, zestawienia najważniejszych tez konfliktu czy kalendaria zdarzeń". ${ }^{20}$

Analiza ekspozycji tytułów wykazała, że tylko jeden z tekstów, a więc „Wielkie interesy króla żylaków i białych zębów”, miał zapowiedź na okładce, nadtytuł „nasze śledztwo” oraz lid. Pozostałe teksty nie miały zapowiedzi na okładce, a „Migdałowy dym. Powrót dopalaczy" nawet nadtytułu (tabela nr 3).

Tabela nr 3: Tytuły analizowanych tekstów

\begin{tabular}{|c|c|c|c|c|}
\hline Nadtytuł & Brak & Nasze śledztwo & $\begin{array}{l}\text { Dziennikarskie } \\
\text { śledztwo }\end{array}$ & Śledztwo \\
\hline Tytuk & $\begin{array}{l}\text { "Migdałowy dym", } \\
\text { Powrót dopalaczy" }\end{array}$ & $\begin{array}{l}\text { „Wielkie interesy króla } \\
\text { żylaków i białych } \\
\text { zębów" }\end{array}$ & $\begin{array}{l}\text { „Miał być cudowny lek. } \\
\text { Są same kłopoty” }\end{array}$ & $\begin{array}{l}\text { „Król białych zębów ma } \\
\text { zarzut. Nie może } \\
\text { wyjechać z Polski” }\end{array}$ \\
\hline Lid & $\begin{array}{l}\text { W małym sklepie z } \\
\text { „pamiątkami” klienci to } \\
\text { nastolatki, kupujące } \\
\text { susz w małych } \\
\text { torebkach. Wg. } \\
\text { instrukcji, do } \\
\text { dosypywania do } \\
\text { kominka. }\end{array}$ & $\begin{array}{l}\text { Zasłynął jako } \\
\text { najmłodszy w Polsce } \\
\text { założyciel prywatnej } \\
\text { kliniki, Gdy interes } \\
\text { padł, Krzysztof } \\
\text { Mazurski przestał być } \\
\text { pupilkiem mediów. } \\
\text { Dziś 22-letni } \\
\text { biznesmen więcej } \\
\text { czasu spędza nad } \\
\text { Atlantykiem niż w } \\
\text { Polsce. Czy dlatego, że } \\
\text { tu grunt zaczyna się } \\
\text { mu palić pod stopami? }\end{array}$ & $\begin{array}{l}\text { Za kampanią } \\
\text { reklamową, m.in. } \\
\text { kontrowersyjnej maści } \\
\text { na żylaki, stoi } \\
\text { „wschodząca gwiazda } \\
\text { biznesu”. Wielu } \\
\text { klientów sygnalizuje } \\
\text { nam, że zostali } \\
\text { oszukani. Policja na } \\
\text { razie próbuje } \\
\text { bagatelizować sprawę. }\end{array}$ & $\begin{array}{l}\text { Piotr K. nazwany } \\
\text { najmłodszym polskim } \\
\text { milionerem, ma dwa } \\
\text { lata więzienia. O jego } \\
\text { interesach pisaliśmy w } \\
\text { styczniu. }\end{array}$ \\
\hline
\end{tabular}

Źródło: opracowanie własne.

Jak uważa Cezary Gmyz, w dziennikarstwie śledczym istnieje święta zasada „o źródłach jak najmniej a najlepiej w ogóle.”21. Czasami dziennikarz śledczy wspomina lakonicznie, że informacje posiada np. z „kręgów władzy” czy od czytelników. W przypadku analizowanych tekstów tylko w jednym przypadku (tabela $\mathrm{nr} 2$ ) autorzy wskazali na czytelników („Wielkie interesy króla żylaków i białych zębów”).

Ostatnim analizowanym zagadnieniem był gatunek dziennikarski, jakim posługiwali się autorzy badanych tekstów. W przypadku publikacji o charakterze śledczym bardzo trudno przypisać im gatunek ze względu na ich niejednorodność, co sygnalizuje Monika Worsowicz ${ }^{22}$. „Migdałowy dym. Powrót dopalaczy” jest sprawozdaniem, a więc rodzajem gatunku informacyjnego: to relacja oparta na faktach. Autorzy przedstawiają wydarzenia w sposób dynamiczny, w porządku czasowym. Fakty są przedstawione

\footnotetext{
${ }^{20}$ M. Worsowicz, Pragmatyka tekstów śledczych..., dz. cyt., s. 132.

${ }^{21}$ C. Gmyz, Zawód: dziennikarz śledczy, Warszawa 2013, s. 15.

${ }^{22}$ M. Worsowicz, Pragmatyka tekstów śledczych..., dz. cyt., s. 123.
} 


\section{OBLICZA MEDIÓW I KOMUNIKACJI}

szczegółowo, a tekst ma postać dłuższej informacji. Tekst „Wielkie interesy króla żylaków i białych zębów" uznać można za reportaż problemowy. Przemawia za tym fakt, że autor występuje w kilku rolach: jest obserwatorem, sprawozdawcą i sędzią. Autor przedstawia fakty, a także relacje innych osób; wysuwa tezy, argumentuje i wnioskuje. Z kolei artykuł „Miał być cudowny lek. Są same kłopoty” jest kontynuacją poprzedniego materiału i także możemy zaliczyć go do reportażu problemowego (publicystycznego), ponieważ wykazuje większość cech tego gatunku. W trzeciej i ostatniej publikacji cyklu pt. „Król białych zębów ma zarzut. Nie może wyjechać z Polski”, autor zastosował odmianę sprawozdania - raport, jeden z gatunków informacyjnych. O przynależności do tego gatunku może świadczyć chronologiczne przywołanie faktów oraz krótki opis wydarzeń i bohatera.

Jak więc widać, teksty, które w wyniku analizy zostały poddane badaniu, nie wykazują jednorodności gatunkowej.

\section{Wnioski i podsumowanie}

Badaniu poddany został rocznik „Dziennika Zachodniego”, czyli 304 numery pisma. Analiza wykazała, że spośród 10032 artykułów tylko 4 można określić jako materiały dziennikarskie o charakterze śledczym. Stanowią one zaledwie $0,042 \%$ powierzchni wszystkich tekstów dziennikarskich.

Wszystkie te teksty odnoszą się do biznesu i działań nieetycznych lub przestępczych. Ich autorami było 4 dziennikarzy pracujących w „tandemach”. Autorzy zastosowali w dwóch przypadkach konwencję reportażu publicystycznego, w jednym odmianę sprawozdania - raport, a w jeszcze innym gatunek informacyjny - sprawozdanie, relację opartą na faktach. Na tej podstawie nie można stwierdzić jednorodności gatunkowej tych tekstów czy istnienia określonego gatunku „reportażu śledczego”.

W badanych artykułach mocno zaznaczała się również tendencja do społecznego piętnowania i negatywnego oceniania działań ich bohaterów - przedstawicieli biznesu.

Znikomy udział dziennikarstwa śledczego w prasie regionalnej ma wiele potencjalnych przyczyn. Może być spowodowany uzależnieniem redakcji od obcego kapitału (w przypadku wydawcy DZ - Polska Press - chodzi o kapitał niemiecki) i zabieganiem o przychylność miejscowych władz. Media lokalne i regionalne są też zależne od reklamodawców - co kłóci się z tropieniem nieprawidłowości w małych i dużych firmach przez dziennikarzy śledczych. Jeszcze innym powodem, wskazywanym często w literaturze, jest niechęć zarządzających do żmudnej, dziennikarskiej pracy, bez szybkich efektów, a często także ich nie gwarantującej. Stąd, częściej możemy zobaczyć materiały, które „udają” tylko materiały śledcze, a w istocie są tekstami interwencyjnymi, relacjami z działań organów ścigania lub innych służb publicznych. Powodem nie mniej częstym jest także lęk przed konsekwencjami prawnymi i finansowymi. Sprawy o zniesławienie oraz naruszenie dóbr osobistych i wynikające z nich wysokie odszkodowania trwale zniechęcają właścicieli wydawnictw do publikacji tekstów, które mogą naruszać czyjąś cześć. Dziś niemal każdy dziennikarz zajmujący się dziennikarstwem śledczym ma na 
swym koncie udział w rozprawie sądowej, gdzie oskarża się go o zniesławienie i żąda odszkodowania od macierzystej redakcji. Sytuacja finansowa mediów lokalnych jest trudna, a obciążenie finansowe w postaci odszkodowania może spowodować, że tytuł zniknie na zawsze z mapy mediów.

Odpowiedź na pytanie o przyczyny tak skromnej liczby tekstów o charakterze śledczym w analizowanym „Dzienniku Zachodnim” wymaga dalszych dociekań, w których pomocne byłyby pogłębione wywiady z dziennikarzami, połączone z ankietą. Wyniki tych dociekań z pewnością pozwoliłyby odpowiedzieć na pytanie, dlaczego w dzienniku o tak dużym zasięgu nie podejmuje się trudnych tematów.

\section{BIBLIOGRAFIA}

Adamczyk W., Rzecz o kontynuacji: amerykańskie wzorce investigative reporting ${ }^{w}$ praktyce polskich reporterów śledczych, w: M. Palczewski, M. Worsowicz, News i dziennikarstwo śledcze wobec wyzwań XXI wieku, Łódź 2010.

Adamczyk W., Skandal na pierwszej stronie. Sensacyjność jako element oceny wiarygodności śledztw dziennikarskich, w: M. Palczewski, M. Worsowicz (red.), O dziennikarstwie śledczym. Normy, zagrożenia, perspektywy, Łódź 2009.

Adamczyk W., Ujawnianie korupcji i nadużyć władzy w działalności amerykańskich muckrakerów, w: red. M. Palczewski, M. Worsowicz, Dziennikarstwo śledcze. Teoria i praktyka w Polsce, Europie i Stanach Zjednoczonych, Łódź 2006.

Braun J., Potęga czwartej władzy, Warszawa 2005.

Brzoza K., Rola Dziennika Zachodniego w wyborach samorządowych 2014, w: S. Michalczyk, D. Krawczyk (red.), Oblicza mediów lokalnych i regionalnych, Mikołów 2016.

Goban-Klas T., Dziennikarstwo śledcze w USA. Powstanie, rozkwit, rozkład, w: red. M. Palczewski, M. Worsowicz, Dziennikarstwo śledcze. Teoria i praktyka w Polsce, Europie i Stanach Zjednoczonych, Łódź 2006.

Hofman I., Polityka, media, społeczeństwo. Studia i szkice, Toruń 2007.

Kittel B., Dziennikarz z dymiącą strzelbą, w: A. Skworza, A. Niziołek (red.), Biblia dziennikarstwa, Kraków 2010.

Kornacka M., Zmierz prasy lokalnej? Ograniczenia w rozwoju prywatnych tytułów lokalnych na przykładzie Śląska Cieszyńskiego, w: W Furman, P. Kuca (red.), Przemiany mediów regionalnych i lokalnych, Rzeszów 2015.

Kowalczyk R., Media lokalne w Polsce. Podręcznik akademicki, Poznań 2009. 


\section{OBLICZA MEDIÓW I KOMUNIKACJI}

Łęski J., Źródła informacji i techniki prascy stosowane $w$ dziennikarstwie dochodzeniowym. Uwagi warsztatowe, w: A. Hejman (red.), Poradnik dla wydawców i dziennikarzy prasy lokalnej, tom 3, Warszawa 1998.

Michalczyk S., Komunikowanie polityczne. Teoretyczne aspekty procesu, Katowice 2005.

Mrozowski M. Media masowe. Władza, rozrywka i biznes, Warszawa 2001.

Worsowicz M, Reportaż, artykuł i... - charakterystyka genologiczna prasowych tekstów śledczych, w: M. Palczewski, M. Worsowicz (red.), O dziennikarstwie śledczym. Normy, zagrożenia, perspektywy, Łódź 2009.

Worsowicz M, Pragmatyka tekstów śledczych. Wybrane zagadnienia, w: tenże (red.), Dziennikarstwo śledcze. Teoria i praktyka w Polsce, Europie i Stanach Zjednoczonych, Łódź 2006.

Wyszyńska M., Lokalni tropiciele, „Press” nr 7-8, 2016.

\section{ŹRODŁA INTERNETOWE}

www.wirtualnemedia.pl

www.freedomhouse.org

\section{OAUTORCE:}

mgr Karolina Polinśsa - absolwentka politologii idziennikarstwa na Wydziale Nauk Społecznych Uniwersytetu Śląskiego, doktorantka stacjonarnych Studiów Doktoranckich Nauki o Polityce, Instytutu Nauk Politycznych i Dziennikarstwa, Uniwersytetu Śląskiego Zakład Komunikacji Społecznej. Pod kierunkiem prof. dr hab. S. Michalczyka przygotowuje dysertację doktorską na temat dziennikarskich materiałów śledczych i ich wpływu na komunikowanie polityczne.Kontakt: ka.polinska@wp.pl 